\title{
Managing the Establishment of Effective Interaction Forms for Regional Agricultural Business Entities
}

\author{
Alexey N. Gerasimov \\ Yevgeny I. Gromov \\ Olga N. Uglitskikh \\ Oksana N. Tsyplakova \\ Irina A. Nevidomskaya
}

Stavropol State Agrarian University, 355017, Russia, Stavropol, Zootechnicallane, 12

Doi:10.5901/mjss.2015.v6n5s2p415

\section{Abstract}

The paper justifies a set of theoretical and methodological propositions and practical guidelines for the establishment and development of spatial economic structures in a region. These structures should be based on the improved system of tools, methods and management for the interaction and performance of business structures. Besides, the authors argue the appropriateness of the regional center of advanced social and economic development (CASED) and test the method for the optimization planning of its effective work founded on activity based costing. This allowed using simulation to assess the effectiveness of management solutions in the interaction of business structures in a region.

Keywords: agrarian business entities; performance; management; interaction; activity based costing; optimization planning.

\section{Introduction}

Regional economic system is constantly influenced by external factors. That is why it should be provided with an opportunity to adapt to new economic conditions (Gerasimov et al., 2014; Sklyarov et al., 2015). One of the prospective development lines of regional economics is the improvement of interaction forms for economic entities, their customers and governmental authorities (Gerasimov et al., 2015; Glotova et al., 2014; Sklyarov and Sklyarova, 2013). In our opinion, the adoption and development of CASEDs in traditionally agrarian regions is a prospective line for the effective interaction between business entities in new economic conditions.

We think that it is grounded to consider a center of advanced social and economic development as a set of financially self-sufficient economic structures able to develop independently, localized within regional economic system and united by common economic interests. The strategic priorities of development include: the introduction of new technologies; the ability to adapt in changing economic conditions; the formation and development of new elements region's economic system which promote its sustainable development.

Such centers can accumulate and realize the high potential of region's business entities leading by industrial and economic criteria (Tomilina et al., 2013; Tatuev and Bahturazova, 2014).

\section{Methods}

In order to make the establishment and work of CASED more practically significant and transparent, we worked out a method how to create and place such a formation. This method is founded on activity based costing. Figure 1 shows the general view of the proposed method.

At the first stage, it is necessary to conduct the general analysis of a regional economic system including its state, functioning conditions and development trends. Activity based costing is one of the most effective ways to reveal economic reserves for the reduction of functional expenses of a CASED by searching for low-cost methods and excluding the ineffective ones.

It must be admitted that one of the main stages of establishing a CASED is the identification of territorial 
peculiarities in the work of agrarian entities and the trends and regularities in the development of region's agricultural sector.

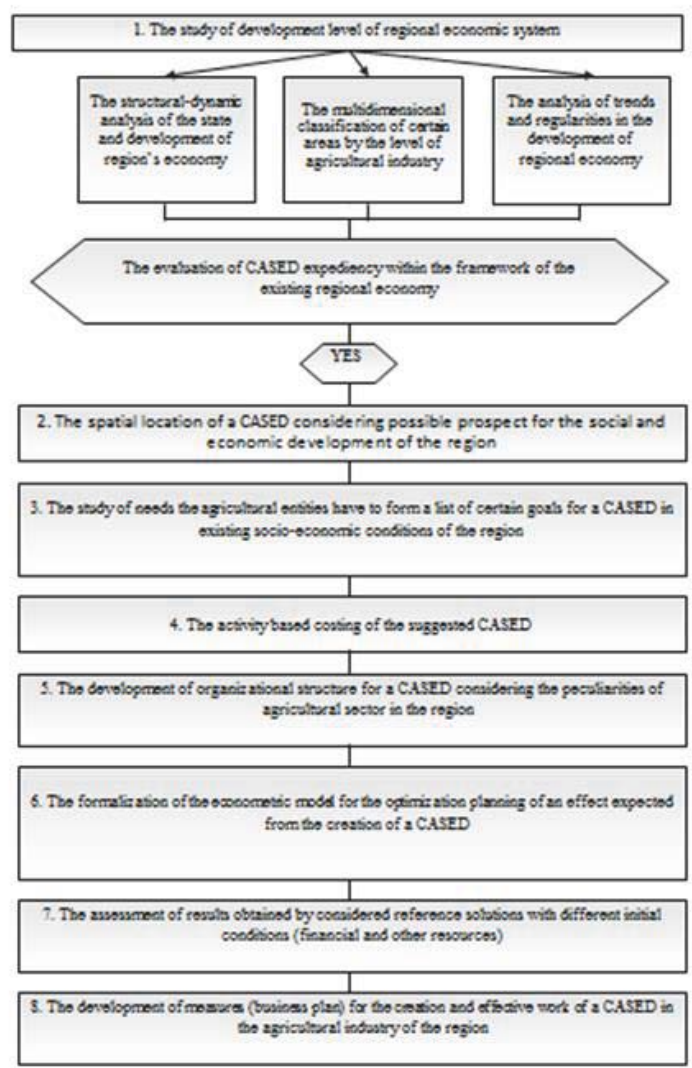

Figure 1 - The method for the creation of regional centers of advanced social and economic development

We suggest a uniform system of estimated figures to classify the territories of a traditionally agrarian region. This system will include the groups of general indicators of agricultural development and the indicators for certain branches. In the paper, we study the municipal districts of the Stavropol Territory. At the first stage, each of them had the following figures from the viewpoint of mentioned groups for the period 2008-2014:

The group of figures indicating the overall developmental level of agricultural sector:

$x_{1}$ - the share of profitable agricultural enterprises, $\%$

$x_{2}-$ proceeds from the sale of plant production, mln. rubles.

$x_{3}-$ the level of profit (damage) from the sales of plant production in the district, mln. rubles

$x_{4}-$ plant production costs, $\mathrm{mln}$. rubles

$x_{5}-$ subsidies from budgets of all levels, mln. rubles

$x_{6}$ - the profitability of plant production, $\%$

$x_{7}-$ short-term credits, $\mathrm{mln}$. rubles

The group of figures indicating the developmental level of livestock products:

$x_{8}$ - the share of profitable agricultural enterprises, $\%$

$x_{9}$ - proceeds from the sale of livestock products, mln. rubles

$x_{10}$ - the level of profit (damage) from the sales of livestock production in the district, mln. rubles

$x_{11}$ - livestock production costs, $\mathrm{mln}$. rubles 
$x_{12}-$ subsidies from budgets of all levels, $m$ ln. rubles

$x_{13}$ - the profitability of livestock products, $\%$

$x_{14}$ - long-term credits, mln. rubles

The group of figures indicating the state and development of the plant sector:

$x_{14}-$ area under cultivation, thous. ha

$x_{16}-$ yield6, dt/ha

$x_{17}-$ output, thous. tons

$x_{18}-$ output sold, thous. tons

$x_{19}$ - average price by all channels, rubles/dt

$x_{20}$ - production costs, rubles

$x_{21}$ - the level of profitability (loss), $\%$

The group of figures indicating the state and development of the livestock sector:

$x_{36}$ - livestock population in all kinds of farms at the beginning of the year, thous. head

$x_{37}$ - average daily gain, $g$

$\chi_{38}$ - production in all kinds of farms, tons (live weight)

$x_{39}$ - production costs, rubles/tons

$x_{40}$ - the level of profitability (loss), $\%$

The general algorithm of the method of multidimensional comparison looks like this:

1. According to initial data, the system of estimated figures is standardized. This allows eliminating the fluctuation of their initial values.

2. The obtained matrix of standardized coefficients is used to calculate the overall rating.

3. The units of the aggregate under study (municipal districts of the region) are ranked in increasing order of rating. A district with the lowest rating will be at the first place.

Figure 2 shows the results of the dynamic comparative analysis of rating for the municipal districts of the Stavropol Territory by the overall developmental level of plant sector for the period 2008-2014.

The plant production development rating for the districts of the Territory for 2008 and 2014 years allowed ascertaining the following clusters shown on Figures 3-4.

As we can see at the presented cartogram, central and northwest districts of the Stavropol Territory lead in the plant sector by scale and performance. In sum, the first group with high estimated figures in 2008 includes 9 districts (or $34.6 \%$ of the total) with rating up to 6.580 points. The top five is formed by Georgievskij $(R=5.185)$, Kochubeevskij $(R=5.388)$, Krasnogvardejskij $(R=5.561)$, Novoaleksandrovskij $(R=5.714)$ and Novoselickij $(R=5.752)$ municipal districts, respectively.

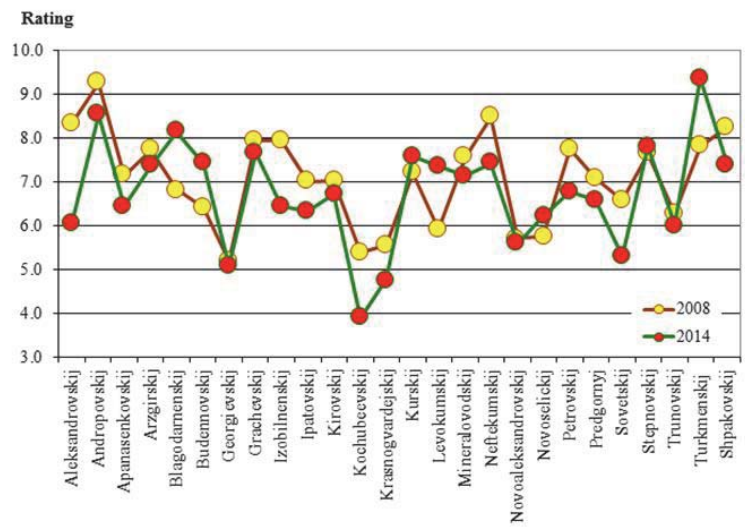

Figure 2 - The rating of municipal districts of the Stavropol Territory by the level of the plant sector for the period 20082014. 


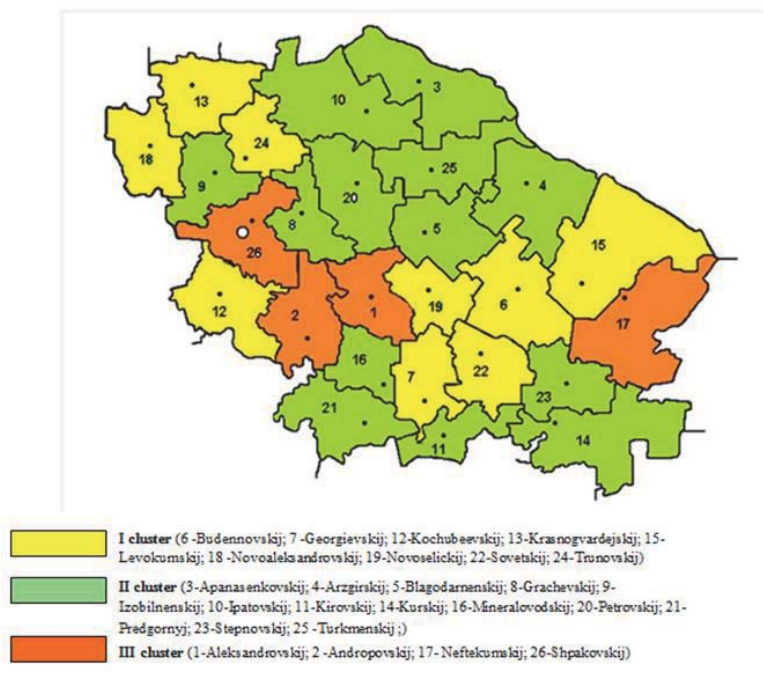

Figure 3 - The rating of municipal districts of the Stavropol Territory according to their level of plant sector (2008)

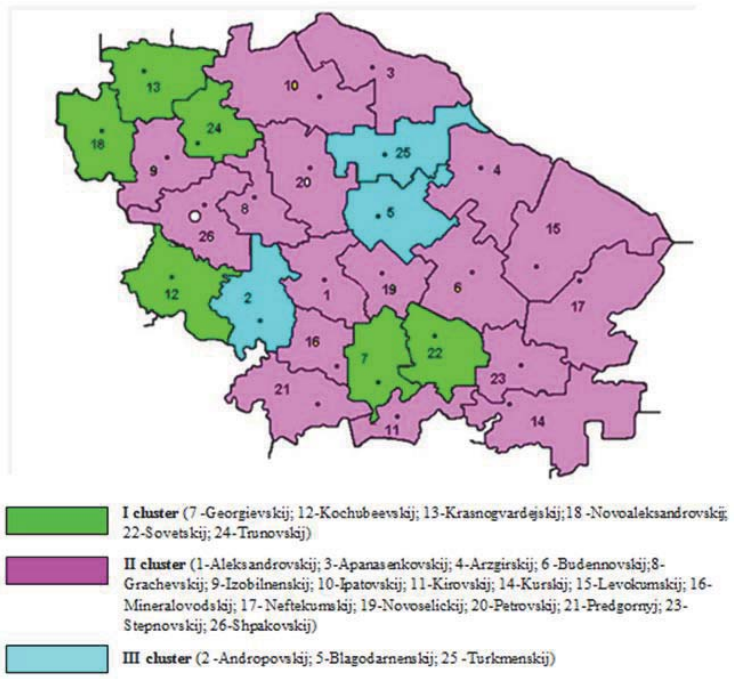

Figure 4 - The rating of municipal districts of the Stavropol Territory according to their level of plant sector (2014)

In 2014, the situation changed: only 6 districts remained in the group of municipal districts with a high level of plant sector. Among them, Kochubeevskij district takes the first place $(R=3.886)$. Then follow Krasnogvardejskij $(R=4,776)$, Georgievskij ( $R=5.086)$, Sovetskij $(R=5.300)$, Novoaleksandrovskij $(R=5.598)$ and Trunovskij $(R=6.022)$ municipal districts. Along with the reduction of the number of areas from the first group, we should note the reduction of absolute rating in comparison with 2008. This testifies to the fact that the level of plant industry grows in this group of districts.

The second group with a medium developmental level of plant sector included 13 districts (or $50 \%$ of the total) with rating from 6.828 to 8.000 points in 2008; and 16 municipal districts in 2014 respectively.

The third group with a low level included 4 districts (or 15.4\%) with rating higher than 8.001 points in 2008 and 3 districts - in 2014. The last three rating positions belong to Blagodarnenskij $(\mathrm{R}=8.146)$, Andropovskij $(\mathrm{R}=8.536)$ And 
Turkmenskij (R=9.369) municipal districts, respectively.

In the same way, we performed a multidimensional comparative analysis of the general developmental level of livestock industry in the Stavropol Territory. The obtained rating of livestock industry for the period 2008-2014 and relevant areas of municipal districts of the region are shown on Figure 5.

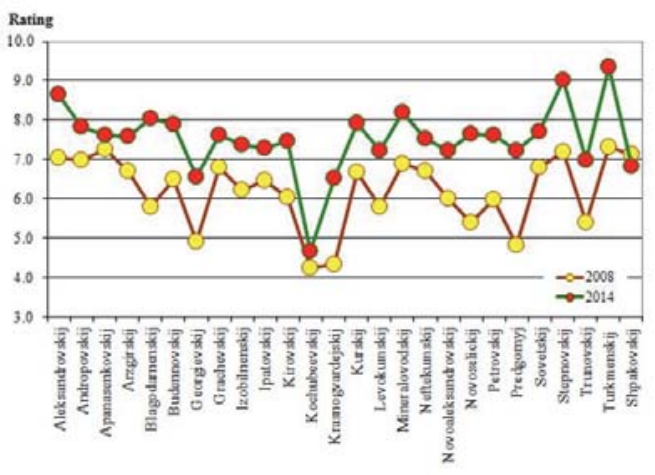

Figure 5 - The rating of municipal districts of the Stavropol Territory according to the level of livestock sector in 20082014

Figures 6-7 show the integrated rating of the districts according to their average level of livestock sector in 2008 and 2014.

The first cluster with high developmental values of livestock industry in 2008 includes 6 municipal districts (23.1\% of the total). Kochubeevskij $(R=4.244)$, Krasnogvardejskij $(R=4.338)$, Predgornyj $(R=4.844)$, Georgievskij $(R=4.927)$ and Trunovskij $(R=5.393)$ municipal districts were the leaders of the group.

In 2014, the number of territories remained the same, although the content changed slightly. The five leaders included Kochubeevskij ( $R=4.671)$, Krasnogvardejskij ( $R=6.525)$, Georgievskij $(R=6.553)$, Shpakovskij $(R=6.842)$ and Trunovskij $(R=9.354)$ municipal districts. It should be noted that the absolute rating changed upward. According to the applied method of multidimensional comparison, this testifies to the fact that the developmental level of livestock sector decreased in 2014 as compared to 2008.
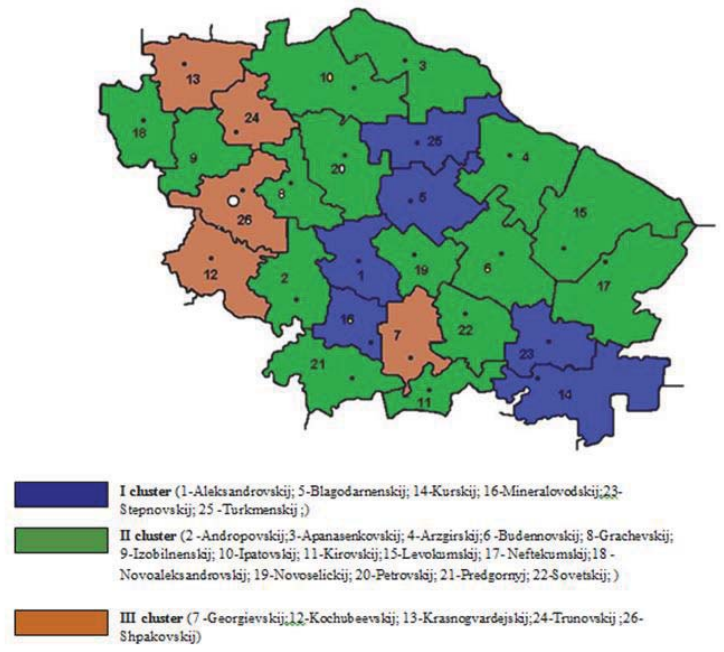

Figure 6 - The rating of municipal districts of the Stavropol Territory according to the level of livestock sector (2008) 


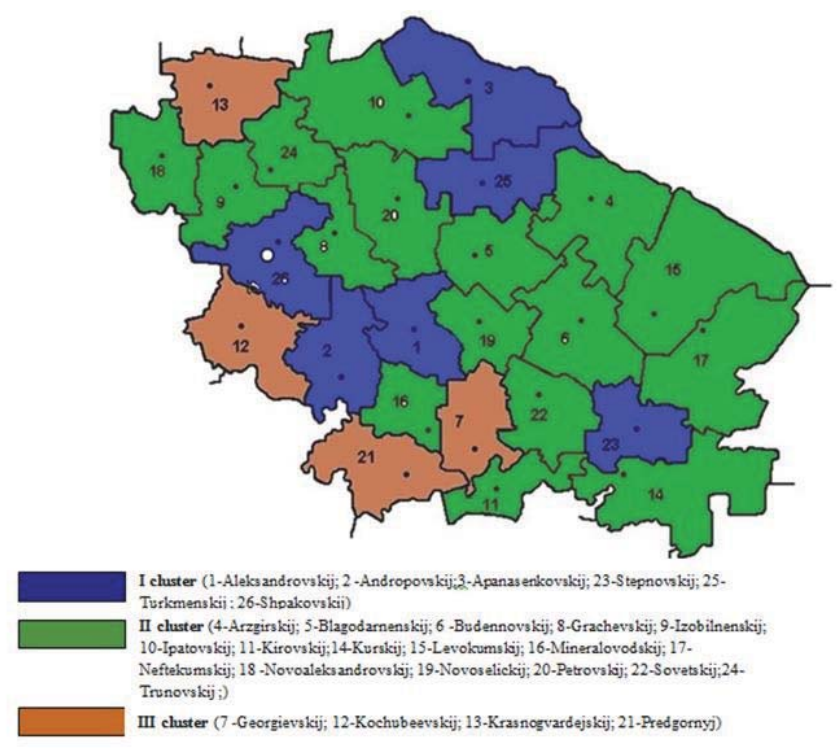

Figure 7 - The rating of municipal districts of Stavropol Territory according to the level of livestock sector (2014)

The second group with a medium developmental level of livestock industry included 15 districts (or $57.7 \%$ of the total) in 2008 and 17 municipal districts in 2014, respectively. The third group with the low level included 5 districts (or 19.2\%) in 2008 and 4 districts in 2014. The last three positions in rating belong to: Stepnovskij ( $R=7.187)$, Apanasenkovskij $(\mathrm{R}=7.257)$ and Turkmenskij ( $\mathrm{R}=7.316)$ municipal districts in 2008, respectively; in 2014: Aleksandrovskij $(\mathrm{R}=8.655)$, Stepnovskij ( $R=9.029)$ and Turkmenskij ( $R=9.354)$ municipal districts.

The multidimensional classification of municipal districts of the Stavropol Territory according to the developmental level of agricultural sectors made it possible to detect that livestock industry is not so effective in Arzgirskij, Apanasenkovskij and Turkmenskij districts as compared to other areas. At the same time, the mentioned administrative divisions of the region have a number of prerequisites for advanced social and economic development connected first of all with the development of specialized sectors of agricultural industry. The conclusions we made allowed us to propose establishing a CASED within the spatial boundaries of the listed districts.

\section{Findings}

The creation of centers of advanced social and economic development makes it possible to coordinate agricultural production activities of all their organizations and services, to unite and reconcile their economic interests and to increase the general effectiveness of agrarian business entities entering these centers (Tatuev et al., 2015; Trukhachev et al., 2014; Uglitskikh and Klishina, 2014).

On the whole, our method for the formation of centers of advanced social and economic development in the agriculture of the Stavropol Territory allows choosing the most important specialized sectors of agricultural industry in compliance with consumers' needs and at the same time assessing the economic and social significance of CASEDs within the location. In order to modernize the region's economic system, we propose to create a center of advanced social and economic development which will specialize in dairy farming.

The next stage of forming a CASED according to the proposed method is the activity based costing (ABC) of the Center's activity. In this approach, the model of a CASED should be considered as a scope of its functions. The use of $A B C$ is caused by the fact that every product, service and structure are created to satisfy certain needs i.e. to perform certain functions by direct and materialized labour (Skripnichenko, 2011; The Agrarian Economy of the Stavropol Territory, 2014; Tatuev, 2010). The general view of the algorithm for this approach used in our research can be presented the following way:

1) setting the goal of the study; 
2) informational stage;

3) the stage of optimization and simulation;

4) result testing.

At the first stage, the goal of the study is set, the object and subject of the $A B C$ is determined and a detailed plan for the study is worked out. The main goal of the study is to stir up and develop the subjects of spatial economic structures in the regional economic system. The proposed agricultural CASED serves are an object of the study.

At the informational stage we differentiate the studied object by its functions and classify them. The development of an institutional infrastructure in the regional dairy farming is the main function of the Center. The Center performs this function by a step-by-step production chain.

An important part of the method is the development of econometric tools which can be useful in reaching the goals. This determined the direction of further research.

The models of linear programming are used as a mathematical apparatus for economic models. Linear programming allows choosing an optimal solution and to maximize the income of each participant in the presence of certain limitations (Lescheva et al., 2014; Erokhin et al., 2014; Trukhachev et al., 2015).

While setting a goal of optimization, we distinguish the following levels and groups of indicators for different stages of production and sale of dairy farming products:

- dairy production;

- sale of dairy products;

- processing of dairy products;

- sale of milk and dairy products.

The year is divided into four quarters: $t=1,2,3,4$. Thus we introduce the following variables:

$v^{0}+$ the volume of dairy products, t.;

$z^{0}+$ dairy production costs, rubles/dt;

$v^{1}-$ the volume of sale of dairy products, t.;

$p^{0} t$ - the price of dairy products, roubles/dt.;

$V^{2}-$ the volume of dairy products sold, t.;

$p^{1} / q$ - the sale of dairy products by different kinds and channels, rubles/t.

We letter parameters that reflect the limitations for resources and facilities as $b_{1}, b_{2}, \ldots, b_{k}$.

It is known that the mathematical description of a model has two parts: target function and limitations (Bobryshev et al., 2014; Gerasimov et al., 2014; Tatuev, 2012). In view of the above, let us present target function $F$ which expresses the maximal sales profit from finished products by reaching the maximal balance between price and cumulative production costs of participants that enter a CASED established in chosen municipal districts of the Stavropol Territory. The target function consists of several blocks and looks like this:

$P=F\left(\sum_{i=1}^{4} \sum_{j=1}^{n} D_{i j}-\sum_{i=1}^{4} S_{i}\right) \rightarrow \mathrm{max}$

where $D_{i j}$ is the profit of CASED participants from finished products in $i$ quarter;

$S_{i}$ are the cumulative costs of CASED participants in $i$ quarter;

$i=1,2,3,4$ is the serial number of a quarter;

$j=1,2, \ldots n$ is a kind of product produced within the framework of the CASED.

$\sum_{i=1}^{4} S_{i}=\left(S_{M}+S_{R}+S_{S T}+S_{m e}\right)$

where $S_{M}$ is the block of production costs for dairy products;

$S_{R}$ is the block of processing costs for dairy products;

$S_{S T}$ is the block of transportation costs and sales costs;

$S_{m e}$ is the block of organizational and management costs for the CASED.

The formalized content of each block:

1. The block of dairy products sale:

$$
\sum_{i=1}^{4} \sum_{j=1}^{n} D_{i j}=\sum_{i=1}^{I} \sum_{j=1}^{J} \sum_{l=1}^{L} \sum_{q=1}^{Q} p_{i j l q} \times v^{\prime}{ }_{i j l q} \text {, }
$$

where $I$ is the number of time periods;

$J$ is the number of manufacturing operations within a CASED;

$L$ is the number of kinds of products;

$Q$ is the number of sales channels; 
$p$ is the sale price, rubles/dt;

$v^{1}$ is the volume of sales, $t$.

2. The block of production costs for dairy products:

$$
S_{M}=\sum_{i=1}^{I} \sum_{j=1}^{J} \sum_{h=1}^{H} z^{0}{ }^{i j h} \times v^{0}{ }_{i j h}
$$

where $H$ is the number of manufacturers in a CASED;

$z^{0}$ are production costs, rubles/dt;

$v^{0}$ is the net output, t.

3. The block of processing costs in dairy farming:

$$
S_{R}=\sum_{i=1}^{I} \sum_{j=1}^{J} \sum_{l=1}^{L} \sum_{h=1}^{H} z^{2} i j / h \times v^{3} i j / h
$$

where $L$ is the number of kinds of products;

$z^{2}$ are the processing costs for dairy farming, rubles/dt.;

$v^{3}$ is the volume of processed products, t.

4. The block of transportation costs and sales costs:

$$
S_{S T}=\sum_{i=1}^{I} \sum_{j=1}^{J}\left(\sum_{l=1}^{L} z^{3}{ }_{i j l} \times v^{4}{ }_{i j l}+\sum_{n=1}^{N} \sum_{h=1}^{H} z^{4}{ }_{i j n h} \times v^{5}{ }_{i j n h}\right)
$$

where $z^{4}$ are the costs for selling 1 t. of products, rubles/t.;

$v^{5}$ the volume of sold products, t.;

$N$ the number of transport nodes;

$z^{3}$ are the transportation costs, rubles/t. $\times \mathrm{km}$;

$v^{4}$ is the volume of finished products transported, t.

5. The block of organizational and management costs for a local CASED:

$$
S_{m e}=\sum_{i=1}^{I} \sum_{j=1}^{J} \sum_{h=1}^{H} m_{i j h} * e_{i j h}
$$

where $m$ are the labour costs, man hours;

$e$ is the salary, rubles.

We showed production optimization in a CASED by the example of a mathematical economic model for an association of agricultural manufacturers. This model is built using a computer and Microsoft Excel to search for optimal solutions (Uglitskikh and Klishina, 2014).

By analyzing calculation results, we obtained an optimal system for the work of agricultural manufacturers including

\begin{tabular}{|c|c|c|c|c|c|c|c|c|}
\hline \multirow[b]{2}{*}{ Municipal districts } & \multicolumn{4}{|c|}{2012 (before the CASED) } & \multicolumn{4}{|c|}{ Averaged predicted values of 2014-2015 (in the CASED) } \\
\hline & $\begin{array}{c}\text { Average milk } \\
\text { yield, } \mathrm{kg}\end{array}$ & $\begin{array}{l}\text { Milk sale, } \\
\text { thous. t. }\end{array}$ & $\begin{array}{l}\text { Milk prime } \\
\text { cost, rub./dt }\end{array}$ & $\begin{array}{c}\text { Profitability, } \\
\%\end{array}$ & $\begin{array}{c}\text { Average milk } \\
\text { yield, kg }\end{array}$ & $\begin{array}{l}\text { Milk sale, } \\
\text { thous. t. }\end{array}$ & \begin{tabular}{|c|} 
Milk prime \\
cost, rub./dt
\end{tabular} & Profitability, \% \\
\hline Apanasenkovskij & 2613.1 & 739 & 12866 & -2.6 & 2639.2 & 812.9 & 12094.0 & 9.8 \\
\hline Arzgirs & 2583.6 & 458.18 & 13194 & -3.8 & 09.4 & 504.0 & 12402.4 & 8.6 \\
\hline Turkmenskij & 2628.4 & 478.76 & 13745 & -2.3 & 2654.7 & 526.6 & 12920.3 & 7.8 \\
\hline
\end{tabular}
production, storage and processing within the framework of a local center of advanced social and economic development (Table 1).

Table 1 - Current and predicted results of the CASED's activities in the region

\section{Discussion}

The application of this mathematical economic optimization model to certain business entities of the agricultural sector of the region will make it possible to get information about optimal indices showing the effectiveness of participation in the CASED. Consequently, today such integrated organizational and industrial structures based on the interweaving of technologically interconnected agrarian, industrial, financial and trade capitals as the center of advanced social and economic development can become one of prerequisites necessary for the development of integrated links between enterprises from different agricultural spheres of the Stavropol Territory.

So, the formation of regional CASEDs seems to be a promising direction for the improvement of the organizational 
and economic mechanism used by agricultural business entities to increase the effectiveness of their work and interaction.

\section{Conclusion}

The performed study allows us to conclude that local centers of advanced social and economic development formed in regional agricultural sector optimize the interaction between agricultural manufacturers that differ in their production output, legal form and agrarian specialization. The unification of economic goals helps industry to integrate into a continuous process flow. This eliminates unnecessary links which usually appear as intermediary services including transportation, storage and sale of agricultural products and resources.

As a result of the study, we admitted that one of the most promising strategic scenarios for regional economic system is the establishment and development of centers of advanced social and economic growth. In order to increase the practical importance of studying the centers of advanced social and economic development (CASED), we worked out a method for the establishment and placement of such structures with the help of activity based costing. The method of multidimensional comparison applied to municipal districts of the Stavropol Territory according to the level of their agricultural industry allowed us to detect the asymmetric development and considerable differentiation of the region's districts.

From the viewpoint of practical importance, the results of the study can be of interest for processing plants in the eastern part of the Stavropol Territory (Arzgirskij, Apanasenkovskij and Turkmenskij municipal districts).

\section{Acknowledgements}

The authors express a deep gratitude to the Chancellor of the Stavropol State Agrarian University Professor Vladimir Ivanovich Trukhachov for the opportunity to perform the research in innovative laboratories of the University.

\section{References}

Bobryshev, A.N., Uryadova, T.N., Lyubenkova, E.P., Yakovenko, V.S. \& Alekseeva, O.A. (2014). Analytical and management approaches to modeling of the accounting balance sheet. Life Science Journal, 11(8), 502-506.

Erokhin, V., Ivolga, A. \& Heijman, W. (2014). Trade liberalization and state support of agriculture: Effects for developing countries. Agricultural Economics (Czech Republic), 60(11), 524-537.

Gerasimov, A.N., Gromov, Y.I. \& Skripnichenko, Y.S. (2015). Assessing of the prospects for the creation of advanced socioeconomic development centers in the agricultural sector of the Stavropol Krai. Actual Problems of Economics, 164 (2), 396-402.

Gerasimov, A.N., Gromov, E.I. \& Shatalova, O.I. (2014). Implementation of econometric approach to determination of prospective directions in development of local markets of crop products. Actual Problems of Economics, 156 (10), 456-465

Gerasimov, A.N., Gromov, E.I. \& Skripnichenko, Y.S. (2014). Development of localized in space economies in traditionally agricultural regions of Russian Federation. Actual Problems of Economics, 156 (6), 264-276

Glotova I.I., Tomilina E.P. \& Kuzmenko I.P. (2014). Modeling the processes of own working capital reproduction in agricultural organizations. Life Science Journal, 11 (5), 536-541.

Lescheva, M.G., Ivolga, A.G. \& Labenko O.M. (2014). Special methodological aspects of economic analysis for rural territories development. Actual Problems of Economics, 159(9), 432-439.

Sklyarov, I.Y. \& Sklyarova, Y.M. (2013). Development of small forms of entrepreneurship and agricultural production in Russian village. Middle East Journal of Scientific Research, 17 (4), 424-428.

Sklyarov, I.Y., Sklyarova, Y.M., Latysheva, L.A. \& Podkolzina, I.M. (2015). Published by Canadian Center of Science and Education. The Evaluation of the Agro-Business Resource Potential in Southern. Asian Social Science, 11 (3), 305-312.

Tatuev, A.A. \& Bahturazova, T.V. (2014). Personal savings: controversial role in extended reproduction. Life Science Journal,11(12), 375-379

Tatuev, A.A., Edelev, D.A. \& Zhankaziev, A.H. (2015). The State Unified Exam as a Requirement in Russia's New Economic Relations. Asian Social Science, 11(6), 1165-1172.

Tomilina, E.P., Glotova I.I. \& Kuzmenko, I.P. (2013). Development of integration processes in the traditional sectors of agriculture. Middle East Journal of Scientific Research, 13 (SPLISSUE), 178-182.

Trukhachev, V., Ivolga, A. \& Lescheva, M. (2015). Enhancement of land tenure relations as a factor of sustainable agricultural development: Case of Stavropol Krai, Russia. Sustainability (Switzerland), 1 (7), 164-179

Trukhachev, V.I., Mazloev, V.Z., Sklyarov, I.Y. \& Sklyarova, Y.M. (2014). Analysis of the market for agricultural products in South Russia. American-Eurasian Journal of Sustainable Agriculture, 8(6), 52-59.

Uglitskikh, O.N. \& Klishina, J.E. (2013). Modeling interregional inter-branch relations as an element of interaction between the branches of the agroindustrial complex. Middle East Journal of Scientific Research, 13(SPLISSUE), 183-190. 
Uglitskikh, O.N. \& Klishina, J.E. (2014). Providing financial support for nature conservation activities in regions. Life Science Journal, 11 (10), 543-547.

Agrarian economy of Stavropol Territory: problems of functioning and development prospects. (2014). Eds., Trukhachev, V.I. Stavropol: AGRUS, 580.

Skripnichenko, U.S. (2011). The cluster approach to the construction of territorial-production systems. Bulletin of the University (State University of Management), 24, 221-223.

Tatuev, A.A. (2010). Direction of the transformation of regional development, Terra Economicus, 8(4-3), 97-100.

Tatuev, A.A. (2012). Priorities of modernization of socio-economic development of the region, Economicheskie Nauki, 87, 71-75. 